\title{
Islamic Education Development Strategy In Facing The Global Challenges
}

\author{
Dr. H. Achmad Asrori, MA \\ Teaching Staff at Faculty of Tarbiyah, State Institute for Islamic Studies Raden Intan, Lampung, Indonesia \\ Assistant Director at Postgraduate School of State Institute for Islamic Studies Raden Intan, Lampung, Indonesia
}

\begin{abstract}
Globalization era is the reality that we ought to face. The ongoing changes and some problems of education as the impact of globalization must be faced and solved as well as possible both on discourse and concrete or action policy phases. Inevitably, the Islamic education will be involved and insisted to be able to give a significant contribution. This paper describes urgency of the Islamic education to reconstruct its self before, both in the institutional management programs and learning aspects, and we must realize that the religious education has the important role in the national education system as "core of education" What must be reconstructed, why and how to reconstruct the Islamic education? This paper answer those questions.
\end{abstract}

Keywords: development, global challenges, Islamic education, Madrasa, reconstruction

\section{Introduction}

The globalization era has become a reality that must be faced by the people and nation of Indonesia. As a result of globalization, everything changes rapidly. This should be considered as a challenge that we need tocope with. In time like this, we need to take action. Islamic education is inevitably involved in the globalization and demanded to be able to contribute significantly.

Today, the world of education in general is facing a variety of challenges, such as: first, globalization in the fields of culture, ethics and morals as a consequence of the advanced technology in transportation and information. Second, the implementation of free trade policy which means the competition is getting tougher for graduates to look for the jobs. In reality, the number of foreign workers who come to work in Indonesia is increasing, while the number of Indonesian workers sent abroad does not showa significant increase, furthermore generally those who work abroad are non-professional ones. Third, international survey results indicate that the quality of education in Indonesia is still low, in addition Indonesia always ranks under other neighboring countries. Fourth, the problem of this country is that it has a low level of social-capital. While the core idea of social-capital is trust, experts say that Indonesia nearly reaches the point of "zero trust society" which means Indonesian people are hard to trust. Among the indicators is the survey of the Political and Economic Risk Consultancy (PERC) in 2004 that the index of corruption in Indonesia has reached 9.25 or the first rank in Asia, in 2005 the indexincreased to 9.4. Fifth, conflicts within relationships between human beings, either as individuals or groups, even as a nation often use religion to legitimize violence. The growth of conflicts, on one hand is a part of social dynamics, but on the other hand threatens the harmony, and even further jeopardizes the social integration at local, national, regional and international level. Sixth, the schools/Madrasa and colleges do not capable in forming a virtuous civil society.

All those challenges above require us to conducthjjra of which the true meaning is to migrate from one state to another in order to achieve the baili or better conditions. The problem is how we should migrate, in the sense of changing the strategy of developing Islamic education in order to face the various challenges mentioned above?

\section{Research Method}

This research method literature review that by collecting various sources of literature from various places. The reason the author uses this method is due essentially. This study is a qualitative research. In addition, this method is considered quite appropriate to approach theproblemto be studied. Afterall sourcescollected, thenclassification,verification to answer research questions. All data collected from these sources are then analyzed in depth so clearly defined answers to the problems studied. Reportthe results of this research are presented with descriptions analysis pattern.

\section{Result of Research}

The Reconstruction of Islamic Education to Face the Global Challenges

\section{Madrasa Reconstruction}

Historically, Madrasahad been developed, by and for the community, therefore this kind of educational institution actually had applied the concept of community-based education on the first hand. Community, both as individuals and organizations, build Madrasaato meet their needs of education. For this reason, Madrasa can be found in the most modest places with the simplestbuildings. The founders undoubtedly are driven by religious passion or missionary effort, and the results come out satisfying.

Until now the $91.4 \%$ out of the total number ofMadrasa (MI, MTs and MA) in Indonesia are privately owned, while the rest are state schools. This data pictures the spirit of Islamic community to fulfill their needs for education independently. Again, these Madrasaare built based on religious spirit, however through Madrasa, the community not only accommodate a large number of students but also take part in the success of 9- years Compulsory Education program. Unfortunately,this high spirit to educate the community does not come hand in hand with professionalism in the 


\section{International Journal of Science and Research (IJSR) \\ ISSN (Online): 2319-7064}

Index Copernicus Value (2013): 6.14 | Impact Factor (2014): 5.611

management of Madrasa. Commonly, Madrasahas not been supported by credible internal resources, both in the development of educational programs (curriculum), learning systems, human resources, financial resources as well as adequate infrastructure. Considering this fact, improvement in most of Madrasais urgently needed.

Recently, this religious spirit has to deal with new demands, especially related to the National Education Standards, which is regulated in GovernmentalRegulations from the Ministry of Education. The National Education Standards are the minimum criteria of the education system in the entire territory of Republic of Indonesia, which consists of 8 (eight) standards namely: content standard, process standard, competency standard, teachers and educational staff standard, facilities and infrastructure standard, management standard, financial standard, and educational assessment standard. Thus, every Madrasa is required to meet these standards to further improve its quality.

Inthe socialization of Development and Quality Improvement of Madrasapolicy, Director General of Islamic Education states that there are several challenges faced by Madrasaboth internally and externally.Internally, the challenges are related to: (1) Quality; Madrasagenerally have not been able to provide qualified graduates, (2) Teaching staff; the majority of teaching staff in Madrasahave not been able to meet the qualifications as standardized by the official regulation, (3) Curriculum; most of the Madrasahave not been able to implement the standardized content standards, as a result the graduates have not been fully able to achieve the minimum competency standards. The percentage of students who pass the National Exam is quite encouraging, approximately $92 \%$, but the average grade acquisition is low, (4) Management; the management of Madrasa of which $91.4 \%$ are private, generally have not been managed professionally, (5) Infrastructure; inadequate infrastructure found in most Madrasa, (6) Status; most Madrasa have not yet fully confident to manage and implement their education. Furthermore, there are only limited opportunities for private Madrasa to change their status into state schools. There are only $8.6 \%$ of all Madrasa are state schools, this state-owned Madrasa generally have met the minimum standards. Externally, the challenge is related to the perception of society and government which tend to be discriminatory, subsequentlyMadrasa receive less attention, including the provision of budget, and some even considered Madrasa as second-class educational institutions.

In order to face both internal and external as well as the global challenges, Madrasa should be able to produce excellent graduates who will be able to create employment opportunitiesand able to compete in the local, national and international labor markets.Excellent graduates should have the following characteristics: (a) excellent knowledge, skills, attitudes and personal integrity, and (b) competitive and acknowledgeable at the national, regional and internationallevels. TheGeneral Director of Islamic Education has set three indicators of excellent graduates, namely: (1) they should achieve the National Standards; Madrasa students should be able to excel in taking the National Exam and graduate with honorstherefore they can continue their education to higher level; (2) they should be competitive; Madrasa graduates should be able to compete with graduates from other schools, and (3) they should meet the expectations of stakeholders; they are able to meet the expectations and needs of parents, community, workplace, government, etc.

To produce these excellent graduates, Madrasa should perform hijra, and improve the management. Therefore, it is necessary to reconstruct themselves, in the sense of change, innovation, and renewal. These are the "keywords" that need to be used as a starting point in developing Madrasah. The changes should come from a clear vision, which is then translated into a mission, and supported by skills, incentives, resources (physical and non-physical, including human resources), to further manifested in a clear work plan. Thus, there will be changes. If there is one aspect as mentioned above missing, there will be consequences. For example, if the development ofMadrasa does not come from a clear vision, there is a chance that it would not come out successfully. A clear vision without a comprehensible mission might result in confusion experienced by everyone who is responsible in the development. Further, nothing would run efficiently without a well-planned budget, and so on.

Reconstruction, change and innovation themselves should be considered as means not goals. To reconstruct means to improve the quality of education, therefore eachMadrasa is required to organize and manage its education seriously.Madrasa should be able to provide quality assurance, capable of providing a prime service, and able to take responsibility for its performance to students, parents, communities or other stakeholders.

In order to accomplish the reconstruction, a Madrasaideally should be lead by a principal who possess these characters, namely: (1) willingness to take risk, (2) desire for renewal; (3) willingness to organize, (4) high expectations; (5) positive attitude, and (6) and courage to come forward. The success of developing a Madrasa cannot be separated from the role of a principal with those six qualities.

Briefly, what is meant by reconstruction isthe improvement of Madrasa management by putting more attention to quality, developing and empowering qualified and competent human resources, as well as implementing the national education policy to meet the national standards, or even achieving higher standardsto gain recognition at national, regional and international levels.

Madrasa is an Islamic educational institution held with the desire and intention to embody the values of Islam in all its educational activities. Managinga Madrasa means managing an Islamic education with values of Islam as the main references. Some of the important teachings and values of Islam to improve the management quality of a Madrasaare as follows:

First, Islam is a religion of practice (praxis). The core teaching is that people earn God's blessing or ridhaby doing good deeds and by worshipping only God (Surah al-Kahf: 110). It implies that Islam is a religion that teaches

\section{Volume 4 Issue 11, November 2015}




\section{International Journal of Science and Research (IJSR) \\ ISSN (Online): 2319-7064 \\ Index Copernicus Value (2013): 6.14 | Impact Factor (2014): 5.611}

"achievement orientation", as stated in the saying "the appreciation in ignorance society (jahiliyah) is based on heredity, while the appreciation in Islam is based on deeds. Whether a person has a high or low degree of piety (taqwa) is also determined by his/herachievement or his/her quality of good deeds as the actualization of hispotential faith. These values should be the driving force and the work ethic in the Madrasa management.

Second, the first point underlines the essential values that need to be enforced as the characters, attitudes and habits of a person or group in doing their jobs (including the management of Madrasa), namely: "working (managing/leading aMadrasa) should be considered as a worship with a sincere intention, seeking for God's blessing. In addition, managing/leading aMadrasa is the realization of ihsanteaching that tellspeople to do good or to provide the best service to all parties because God has been good to humans, and prohibitus to give terrible service (QS. AlQasas: 77).

The work ethic has the following implications: (1) thata person (manager/leader of aMadrasa) may not work "recklessly" because it would mean degradingthe meaning of "for the sake of Allah's blessing" or in other words demeaningGod. Qur'an Surah al-Kahf: 110, declares: "So whoever hopes for the meeting with his Lord, let him work righteousness and associate none as a partner in the worship of his Lord."; (2) that there shall be nothing for a man except what he strive for(Q.S. al-Najm: 39), therefore, in performing a task or working, every man is required to: (a) take anything he is working on seriously, (b) give meaning to the work, (c) realize that working is a mode of existence (state of beinghuman), and (d) in terms of the impact $(\mathrm{good} / \mathrm{bad})$, realize that work is for God, as well as for himself (readQ.S.Fushshilat: 46, and Luqman: 12), (3) thata person (manager/leader of aMadrasa) should work optimally and commit to the process for the finest result, in harmony with the teachings of ihsan(read Q.S. al-Nahl: 90), (4) that a person (manager/leader of aMadrasa) should work efficiently and effectively or as useful as possible (read Q.S. al-Sajdah: 7), (5) that a person (manager/leader of aMadrasa) should do the work sincerely and thoroughly (itqan), and not half-heartedly for awonderful, orderly, and consistent result (Q.S. al-Naml; 88), (6) that a person (manager/leader of aMadrasa)is required to be actively involved, to have a commitment for a better future, a sense of community as well as the development of science and technology, and to be istiqama (Q.S.ash-Sharh: 7-8; adDhuha: 4; al-'Alaq: 1-3; ash-Shura: 15).

On the other hand, researches show that one of the key for successful school/Madrasa is the leadership or the ability to conduct professional management. Burhanuddin states ".... the essence of the leadership roles of a school principal in enhancing the efforts of school improvement"is important and according to the Dowand Oakley"........... principal leadership is an essential ingredient in creating and maintaining an effective school." Research conducted by Edmonds shows that schools with impressive achievement led by good principals. Edmonds also said that a dynamic organization is always led by a good leader, the leader who is always trying to improve his performance. Fullan (in
Hopkins \&Wideen, 1984) found that the school principal is the agent for school improvement. Rutter (cited by Sergiovanni, 1987) concluded in his research that the school principal is the key to success for improving the quality of outputs (graduates).

The ideas about work ethic drawn fromthe words of God (qauliyahverses)and also the results of researches as qauniyah phenomenon should be used as a stepping stone by school principals in managing Madrasa more professionally, so that itwould have competitive and recognized graduates at the national, regional and international levels.

\section{Reconstruction of Islamic Education in Schools}

Until now the ongoing implementation of Islamic education in schools is still considered to be less successful (not to say "fail") in capturing the diversity of attitudes and behaviors of students and in building the nation's morals and ethics. There are lot arguments that can support the statement, among others is some indications that there are weak points of the implementation of religious education in school. Those weak points are (1) Islamic education can not change the cognitive science of religion intoa "meaningful" and "valuable" science or it can not inspire students to grasp the religious values. In other words, religious education which has been emphasizing more on knowing and doing aspects and not yet leads the aspect of being, i.e., how the students should live according to the religious values (knowing), whereas the core aspects of religious education lay on this, (2) Islamic education cannot cooperate with non-religious education programs, (3) Islamic education has less relevance to the social changes that occur in the community or less illustrate the socio-cultural context, and are static and separated from history, so that the students are lack of appreciation for the religious values as values in everyday life.

It is actually a classical problem, but until now has not been resolved properly, therefore it becomes an ongoing issue from one period of time to the next. There are many internal issues in Islamic education that have yet to be solved properly, but on the other hand the Islamic education is also dealing with external factors such as a strong cultural influence of materialism, consumerism and hedonism, which leads to changes in life-style of the community.

To pay more attention on those challenges faced by Islamic education, presumably the necessary move (hijra) is concerning with the reconstruction of methodological aspect from dogmatic-doctrinal and traditional methods to more dynamics and contextual learning and teaching method. A question arises: whether the contextual approach used in Islamic education would lead to changes in religious values? If so, where do the basic principles of religious beliefs lay? According to the author, ontologicallyand axiological the basic principles of religious teaching will remain as it is, but it will shift epistemologically according to the challenges it is dealing with. Contextual approach in teaching and learning method in Islamic educationincludes in epistemological territory, which stresses on the processes, procedures, and methodologies used to acquire knowledge of Islam, and how to live and practice it.

\section{Volume 4 Issue 11, November 2015}




\section{International Journal of Science and Research (IJSR) \\ ISSN (Online): 2319-7064}

Index Copernicus Value (2013): 6.14 | Impact Factor (2014): 5.611

According to Dirkx, Amey, \& Haston (1999) contextual approach comes from constructivist. According to constructivist learning theory, individuals learn by constructing it through and interpreting the interaction with their environment. Further they state that: "The meaning of what individuals leam is coupled with their life experiences and contexts; it is constructed by the leamers, not by the teachers; and learning is anchored in the context of real-life situations and problems". The characteristics of contextual learning, in accordance with Clifford \& Wilson (2000) are as follows: (1) Emphasizes problem soling; (2) Assist students in learning how to monitor their learning so that they can become self-regulated learners; (4) Anchors teaching in the diverse life context of students; (5) Encourages students to leam from each other' (6) Employs authentic assessement.

Islamic education in school consists of several aspects, namely: aspect of Al-Quran and Al-Hadith, faith/aqidah, morality, fiqh(Islamic law) and aspects of Islamictarikh (history) and culture. These five aspects of Islamiceducation should be taught to students using contextual approach, which is essentially associating the Islamic values with students' diverse life experiences and/or their contextual problems and real life situations. Through their interaction with the surroundingsand their interpretation of Islamic knowledge on their own life experiences, students can construct the meaning and values of Islam. Thus, Islamiccontextual-based learning approach assumes that the laboratory of Islamic education is life itself, whether it is related to family problems, social, economic, political, cultural, science and technology and natural environment and so on.

Islamic education in schools basically is oriented towards moral action stage; not only studentsown competence but also have will and habit in implementingreligious values within their day-to-daylives. According to Lickona (1991), there are three continuous teaching and learning processes to teach students to achieve the moral action level, starting from the process of moral knowing, moral feeling to moral action. All three processes of teaching and learning should be developed in integrated and sustainable way, the first: Moral Knowing, which includes: (1) moral awareness, (2) knowing moral values, (3) perspective-talking, (4) moralreasoning, (5) decision making (6) self-knowledge. Second: Moral Feeling, which includes: (1) conscience, (2) selfesteem (3) empathy, (4) loving the good (5) self-control (6) humility. Third: Moral Action, which includes: (1) competence, (2) will, (3) habit.

Through Islamic contextual-based learning approach and sustainable development process started from the process of moral knowing, moral feeling to moral action, it is expected that students' potencieswould develop optimally; in the aspect of intellectual, emotional intelligence, social intelligence, and spiritual intelligence and kinesthetic intelligence. Intellectual intelligence includes the ability to distinguish between good and bad, right and wrong, as well as to set priorities. Emotional intelligenceinvolves the abilityto control emotions, to understandother people's feelings, to be cooperative, to postpone temporary pleasure, and to have a stable personality. Spiritual intelligenceinvolves the ability to realize that God knows everything that we do, to do everything lillahi ta'ala, to have patience in doing anything, to be thankful and grateful. Whilekinesthetic intelligenceinvolvesphysical health, i.e. medically fit, live fromhalal fortune. It is important to have human resources with all qualities mentioned earlier in order to face the global challenges.

The implementation of contextual approach in religious education requires several basic principals, among other things is the need for a philosophical approach. Faziur Rahman (1982) states that:

"Philosophy is however a perennial intellectual need and has to be allowed to flourish both for its own sake and for the sake of other disciplines, since it inculcates a much-needed analytical and critical spirit that generates new ideas Join us important intellectual tools for other sciences not least for religion and theology. Therefore a people that deprives itself of philosophy necessarily expose itself to starvation in terms of fresh ideas-in fact it commits intellectual suicide ".

One thing that should be underlined from Faziur Rahman'sstatement is that people who ignore philosophy in understanding religious texts, he will lose the actual, contextual, and fresh ideas. Therefore, philosophical approach is necessary for people who want to develop their understanding of religious texts contextually. Secondly, the need to understand and willingness to accept religious mindset. There are three kinds of religious mindsets in terms of the relationship between the meaning of the text and the text itself: (1) monism, the content (meaning) with lafaz or text are inseparable unity. Disagreement in understanding the text is impossible because the two units is united; (2) dualism, that between the content (meaning) with Iafaz or text can be separated, in the sense that each has its own existence, even though there is a relationship, but it is considered as less complex, (3) pluralism, that the relationship between the content (meaning) withlafaz or text is complex. A text constructs metafunctionalmeaning consisting of ideational, interpersonal and textual meanings. So, not only each text has a meaning and form of its own existence, but the relationship between them is very complex.

\section{Repositioning Islamic Education to Face The Global Challenges}

The Indonesian Constitution ofNational Education System states that education is a conscious and deliberate effort to create such an atmosphere and process of teaching and learningin order to allow the students to actively develop their potenciesto have the spiritual strength, self-control, personality, intelligence, noble characters, and skills which are necessary for themselves, society, the nation and the state. In the perspective of Islamic education, the term for human potential is fitra (human nature). Thus, education is a conscious and deliberate effort to create such an atmosphere and process of teaching and learning in order to allow the students to actively develop their potential natural tendencies (fitra) to have the spiritual strength, and so on. As a matter of fact, beside to develop human's potential natural

\section{Volume 4 Issue 11, November 2015}




\section{International Journal of Science and Research (IJSR) \\ ISSN (Online): 2319-7064}

Index Copernicus Value (2013): 6.14 | Impact Factor (2014): 5.611

tendencies (fitra), education also try to save and protect that potency as well as to harmonize it with fitramukhallaqa (natural tendency which God creates for human, namely instinct, jismiyah, nafsiyyah, aqliya and qalbiyah potencies) with the guidelines from munazzala (natural tendency which God creates for human's guidilines in life, that is religion) and allaspects oflife,so thathumanscanlive consistently on therightpathof life, oronthepath of"ash-shirathal-mustaqim".

The Indonesian Constitution ofNational Education System, Article 1, Section 2 states that education is based on Pancasila and the Constitution of Republic of Indonesia which is rooted in religious values, and so on. This important concept is also adapted to the Indonesian Constitution No. 14/2005 on Teachers and Lecturers, as in Articles 6 and 7, in fact it is developed into the first pillar of learning, i.e. learning to have faith and fear of God Almighty.

Both constitutions mentioned above underlinethe importance of hijra, in the sense of changing our understanding and awareness about the position of the original Islamic education which at first seems tobe marginalized, exclusive and considered as the obligation of religion teachers only, intothe attempts to make Islamic education as the "core"education. Thus, Islamic education is not only the task of religion teachers alone, but also the task of principals, all teachers, all school officials, and parents. Islamic education is necessary and should be developed into a school culture as mentioned in the goal of Islamic education in schools above.

It's just that when we talk about Islamic education, it can not be separated from Muslims as the main actors and developers. There aresome negative perceptions on Islamic education even some parties try marginalize it. Islamic education is perceived as "exclusive" and some people accuse that through the Islamic education, there are efforts to establish "Islamic State" and to uphold Islamic law in Indonesia, and so on. Such perception is supported by the fact that the recent conflicts in human relations as an individual or a group, even as a nationtend to put on the legitimacy of the religion (Islam) to legalize their act of violence.

This fact implies that there are still many things that need to be reconsidering in terms of the diversity of religions. Do religious people should see other people (who are not likeminded) as the enemy, as the others? Do all the differencesshould be addressed hostilely, should be fought and resisted? If such attitudes and behaviors prominently emerge in the development of Islamic education in school or in the community, it is only natural that Islamic education become marginalized. It is better for us to build a positive attitude of respecting others who have different point of views as well as different religions, believing that everyone has the same right to live no matter how different they are from us.

The prophet had taught the principal of social integration to build a civil society. Islam teaches the values and knowledge of ta'aruf(to get to know each other) with other groups with different religious, social, and cultural backgrounds in society (Q.S. al-Hujurat: 13). This principle needs to be transformed back into the educational development frameworkto deal with people who are affected by conflicts. Religious education potentially leadsthe students to either tolerance or intolerance behaviors, as well as bulids the integration or disintegration in the society. This phenomenon will be largely determined by at least: (1) religious theology and its teaching doctrine, (2) attitudes and behavior to understand and appreciate the adherents of the religion, (3) socio-cultural environment that surrounds it, and (4) the role and influence of religious leaders, including religious teachers, in directing his followers.

If theology views and teachings are extreme, with symbolic, textual and scriptural models of religious understanding because of the doctrinal and rigid guidance fromthe teachers which would develop an attitude of blind fanaticism, and supported by the exclusive socio-cultural environment then it is possible to create religious intolerance which would lead to disintegrative situation.

In facing the global challenges, the development of Islamic education in Indonesia should consider that Indonesia has a principal of Unity in Diversity. Therefore, the development of Islamic education is expected not to grow: (1) the spirit of blind bigotry, (2) intolerance, and (3) damage the religious harmony and national unity. The development of Islamic education is expected to be able to create an Islamic relationship in a broad sense, the brotherhood that is Islamic, not just brotherhood among Muslims as it has been understood, but is also able to build brotherhood among human beings. According to Islam, all religions must be protected, and all Muslims should be given the freedom to practice his religion. It's just that the concept of religious freedom reflects more the view of life, behavior and mentality of "having a religion". Therefore, it is necessary to develop inter-religious dialogue that would reflect more the attitudes, behavior and mentality of "being religious".

Islamic education position is clearly need to be developed towards:(1) multicultural Islamic education, Islamic education should be set in multicultural characters, acceptance ofcultural, social and religious differences, (2) solidliutammima makarimal akhlaqmission and (3) spiritual national characters, including to spiritualizeall kinds of rules to build a civilized nation.

It takes some basic principals in order to achieve that: first, trying to improve, strengthen and expand their Islamic knowledge and insight. Assuming that the higher a person's knowledge about Islam, the more tolerance he is. Conversely, the less a person's knowledge about Islam, the more negative would he thinksabout others. Second, the breadth of knowledge and insight would have implications for the emergence of attitudes husnuzh-zhan (good prejudice) to others. If a person has bad prejudice from the very beginning towards others then all that is done by the other party shall be seen as terrible things, this would cause the emerge of conflicts. And third, most importantly, no single group can claim a monopoly on truth or, as no single group monopolize mistake.

\section{Volume 4 Issue 11, November 2015}




\section{International Journal of Science and Research (IJSR) \\ ISSN (Online): 2319-7064}

Index Copernicus Value (2013): 6.14 | Impact Factor (2014): 5.611

\section{Conclusion}

The birth ofMadrasa (Islamic education as an institution) that originally was driven by religious zeal and mission with simple management, now faces new challenges both related to its contribution in responding to the global challenges, as well as regarding the implementation of TheIndonesian Governmental Regulations of National Education Standards, No. 19/2005. In order to face the global challenges, Islamic leaders need to emigrate, mainly in terms of the reconstruction of a more professional managerial aspects and the improvement of quality of education, providing quality assurance, excellent service, and responsibility for its work for students, parents, and community as the stakeholders, which in this case is the realization of ihsan teachings.

In the context of the implementation of Islamic education in school, the required move is related to the reconstruction of the methodological aspect, from a doctrinaire and dogmatictraditional learning leads to a more dynamic and contextualactual one. To implement the contextual approach requires some basic principals, among others: philosophical approaches to understandreligious texts in order not to lose actual, contextual, and fresh ideas, as well as the need to understand and willingness to accept different religious mindset.

The Islamic education has an obvious position, but in practice, sometimes false understanding of Islam leads to exclusive attitudes and behaviors, and as a result, put the Islamic education in a marginal position. In order to face the global challenges, we need to emigrate, in the sense of changing our understanding and awareness of the position of the Islamic education which has been marginalized, and is considered as exclusive and often regarded asthe responsibility of religion teacher only, into an attempt to make Islamic education as a "core" education. Thus, Islamic education is not only the task of religion teachers alone, but it is everyone's task, furthermore it should be developed into the school culture.

\section{References}

[1] Abdullah, M. Amin. (2005).Pendidikan Agama Era Multikultural Multireligius.Jakarta: Pusat Studi Agama dan Peradaban (PSAP) Muhammadiyah.

[2] Arkoun, Muhammad. (1990).Al-Fikr Al-Islami Naqd wa Ijtihad. Translated and commented by Hashim Salhi. London: Al-Saqi.

[3] Brown, B. L. (1998). Applying Constructivism in Vocational and Career Education. Information Series No. 378 Columbus: ERIC Clearinghouse on Adult, Career, And Covational Education, Center on Education and Training for Emplyment, College of Education, The Ohio State University.

[4] Burhan Nurgiantoro. (1995). Teori Pengkajian Fiksi. Yogyakarta: Gajah mada University Press.

[5] Burhanuddin. (1993).The Leadership Roles of a Principal in Improving Schoold effectiveness. Thesis. South Austalia: School of Education, The Flinders University.

[6] Clifford, M., and Wilson, M.(2000), "Contextual Teaching, Professional Learning and stundet Experiences : Lessons Learned from Implementation." Educational Brief No. 2
Madison: Center on Education and Work, Univeristy of Wisconsin-Madison, December 2000, p.17.

[7] Dirjen Pendidikan Islam. Kebijakan Departemen Agama RI Dalam Pembinaan dan Peningkatan Mutu Madrasah. Paper presented on Madrasa CurriculumDevelopmentCoordination Meetingon 14-16 November 2007, in Cisarua, Bogor, Indonesia.

[8] Dirkx, J. M., Amey M and Haston, L. (1999), "Context in the Contextualized Curriculum : Adult Life Worlds as Unitary or Multiplistic?" in Proceedings of the $18^{\text {th }}$ Annual Midwest Research to Practice Conference in Adult, Continuing, and community Education, edited by. A. Austin, G.E. Nynes, and R.T. Miller, PP 79-84. St. Louis: University of Missouri at St. Louis.

[9] Dow, I.I., \& Oakely, W.F. School Effectiveness and Leadership. Alberta Journal of Educational Research, 38. (1): $33-45$

[10] Edmonds, R (1979). Some School Work and More Can. Social Policy, 9 (2), 28-32.

[11] Fadjar, A. Malik (2003), Strategi Pengembangan Pendidikan Islam Dalam era Globalisasi. Paper presented on Seminar On Islam and The Challenges of Global education in the New Millenium, The IIUM Alumni Chapter of Indonesia on 26 January 2003, in Pekan Baru, Indonesia.

[12] Hopkins \& Wideen. (1984), Alternative Perspectives On School Improvement. London and New York: The Falmer Press.

[13] Indonesian Constitution of National Education System, No. 20/2003.

[14] Indonesian Constitution of Teachers and Lecturers, No. $14 / 2005$.

[15] Indonesian Governmental Regulations of National Education Standards, No. 19/2005.

[16] Indonesian Ministry of Education Regulations of Competency Standards for Primary and Secondary Education Unit, No. 23/2006.

[17] Indonesian Ministry of Education Regulations, No. 24/2006 on the Guidelines of The Indonesian Ministry of Education Regulations No. 22 and No. 23.

[18] Lickona, Thomas. (1991). Educating for Character How Our Schools Can Teach respect And Responsibility, New York: Bantam Book.

[19] Muhaimin, Suti'ah, and Sugeng Listyo P. (2008). Manajemen Pendidikan Aplikasinya Dalam Penyusunan rencana Pengembangan Sekolah/Madrasah. Jakarta: Prenada.

[20] Muhaimin. (2006). Nuansa Baru Pendidikan Islam Mengurai Benang Kusut Dunia Pendidikan. Jakarta: Raja Grafindo Persada.

[21] Muhaimin. (2008). Pengembangan Kurikulum dan pembelajaran (Upaya Reaktualisasi pendidikan Islam). Malang: Lembaga Konsultasi dan pengembangan Pendidikan Islam (LKP2-I).

[22] Rahman, Fazlur. (1982). Islam and Modernity: Transformation of an Intellectual Tradition. Chicago \& London: The University of Chicago Press.

[23] Sergiovanni, T.J. (1987). The Principalship: a Reflective Practice Perspective. Boston: Allyn and Bacon, inc. 